\title{
Hints at the Applicability of Microalgae and Cyanobacteria for the Biodegradation of Plastics
}

\author{
Giovanni Davide Barone ${ }^{1, *(\mathbb{C}}$, Damir Ferizović ${ }^{2}\left(\mathbb{D}\right.$, Antonino Biundo ${ }^{3,4}$ and Peter Lindblad $^{5}$ (i) \\ 1 Institute of Molecular Biotechnology, Graz University of Technology, 8010 Graz, Austria \\ 2 Institute of Analysis and Number Theory, Graz University of Technology, 8010 Graz, Austria; \\ damir.ferizovic@tugraz.at \\ 3 Department of Bioscience, Biotechnology and Biopharmaceutics, University of Bari, 70125 Bari, Italy; \\ antonino.biundo@gmail.com \\ 4 Interuniversity Consortium for Biotechnology (CIB), 70125 Bari, Italy \\ 5 Department of Chemistry-Ångström Laboratory, Uppsala University, SE-751 20 Uppsala, Sweden; \\ Peter.Lindblad@kemi.uu.se \\ * Correspondence: giovanni.barone@tugraz.at
}

Received: 30 October 2020; Accepted: 10 December 2020; Published: 14 December 2020

\begin{abstract}
Massive plastic accumulation has been taking place across diverse landscapes since the 1950s, when large-scale plastic production started. Nowadays, societies struggle with continuously increasing concerns about the subsequent pollution and environmental stresses that have accompanied this plastic revolution. Degradation of used plastics is highly time-consuming and causes volumetric aggregation, mainly due to their high strength and bulky structure. The size of these agglomerations in marine and freshwater basins increases daily. Exposure to weather conditions and environmental microflora (e.g., bacteria and microalgae) can slowly corrode the plastic structure. As has been well documented in recent years, plastic fragments are widespread in marine basins and partially in main global rivers. These are potential sources of negative effects on global food chains. Cyanobacteria (e.g., Synechocystis sp. PCC 6803, and Synechococcus elongatus PCC 7942), which are photosynthetic microorganisms and were previously identified as blue-green algae, are currently under close attention for their abilities to capture solar energy and the greenhouse gas carbon dioxide for the production of high-value products. In the last few decades, these microorganisms have been exploited for different purposes (e.g., biofuels, antioxidants, fertilizers, and 'superfood' production). Microalgae (e.g., Chlamydomonas reinhardtii, and Phaeodactylum tricornutum) are also suitable for environmental and biotechnological applications based on the exploitation of solar light. Can photosynthetic bacteria and unicellular eukaryotic algae play a role for further scientific research in the bioremediation of plastics of different sizes present in water surfaces? In recent years, several studies have been targeting the utilization of microorganisms for plastic bioremediation. Among the different phyla, the employment of wild-type or engineered cyanobacteria may represent an interesting, environmentally friendly, and sustainable option.
\end{abstract}

Keywords: plastic accumulation; microplastics; environment; bioremediation; microalgae; cyanobacteria

\section{Introduction}

Plastic debris is a widely documented environmental problem and issue of public concern. One of the most ubiquitous and long-lasting recent changes to the surface of the globe is the accumulation and fragmentation of plastics. Plastic marine debris has been recently ranked carefully, according to their environmental degradation trends [1]. Currently, the most common fossil-based polymers are polyethylene terephthalate (PET), polyethylene (PE; low density (LDPE), and high density (HDPE)), 
polyvinylchloride (PVC), polypropylene (PP), and polystyrene (PS). In 2018, the demand for LDPE and HDPE was approximately 9 and 6.25 million metric tons, respectively, in Europe alone [2]. Note that LDPE and HDPE have lower densities than water, explaining their buoyancy. Carry bags, which are usually made from LDPE, are in widespread use for consumer products and are generally resistant to deterioration [3]. Due to the release of toxic compounds into the environment, products containing pro-oxidant additives have been introduced as new materials with promising biodegradability [3].

The use of plastic materials has advantages and disadvantages, as huge societal benefits have arisen from its utilization, especially due to their ease of production, low cost, and wide applicability. However, the 'plastic age' has negatively impacted the natural landscape and the lifetime of several wild species. One issue of emerging concern is the aggregation of plastics in the aquatic environment. Nowadays, numerous data documenting massive plastic accumulation in water are easily available. Plastic fragments diametrically smaller than $5 \mathrm{~mm}$ are generally referred to as microplastics, and as nanoplastics if the diameters are in the nanoscale [3,4]. No analytical methods exist for the identification and quantification of nanoplastics in food, and generally, there is little information [4].

Small-scale fragments are of special concern due to their entrance into the food chain and being able to absorb contaminants. The average size of plastic particles in the environment seems to have decreased, and the abundance and global distribution of microplastic fragments have increased significantly over the last few decades. Population size and the quality of country waste management systems largely determine the mass of uncaptured waste available to become marine plastic debris. Plastics typically constitute approximately $10 \%$ of discarded waste, but the impact is very severe through the accumulation of debris in terrestrial environments and open oceans [5]. Plastics have been considered a key geological indicator of the Anthropocene, as a peculiar constituent [6]. Studies about microplastics in various environments have highlighted the ubiquity of synthetic fibers $[7,8]$. Without waste management infrastructure improvements, the cumulative quantity of plastic waste available to enter the ocean from land has been predicted to increase from about 8.8 million metric tons in 2010 to 88 million metric tons by 2025 [9].

Environmental scientists have intensively started to investigate microplastics in aquatic environments since the early 2000s. Research on marine plastic pollution is more advanced and its ingestion has been documented in several sea creatures: the majority of available studies deal with fishes and sea mammals (e.g., dolphins, and seals), and the second most studied group are bivalves (e.g., mussels, clams, and scallops) [10,11]. Data from freshwater ecosystems are less abundant than coastal regions, but the studies also provide evidence for the presence of microplastics in rivers, lakes, and tap water [12-20].

Synthetic biology, genetic engineering, nanotechnologies, and emerging biotreatment technologies have the potential to achieve important societal targets [21]. Further, the removal of pollutants via biosorption has been applied for decades as a cost-effective method to clean the environment [22]. Regarding plastic pollution, certain studies have investigated the interactions of plastic particles with photosynthetic microalgae and cyanobacteria (e.g., Chlorella, Scenedesmus, Raphidocelis subcapitata, C. reinhardtii, Anabaena sp. PCC 7120) [23-25]. Related results often show the presence of induced intracellular Reactive Oxygen Species (ROS), indicating that these pollutants can be a source of stress also for photosynthetic microorganisms. One of the most studied microalgae is C. reinhardtii (order: Chlamydomonodales, class: Chlorophyceae; see algaebase.org) [26,27]. Investigations using this model unicellular green algae have been focused on its biotechnological applications (e.g., bioproducts), flagella, algal photosynthesis and physiology, and even genome integrity [26,28]. The Chlamydomonas Genetics Center has provided C. reinhardtii, wild-type and mutant strains, its relatives, and resources such as plasmids for cell engineering [27]. Interestingly, the application of $C$. reinhardtii for PET degradation has been recently shown [29]. A less intensive studied microalga, the marine diatom P. tricornutum, was also newly applied as a cell factory to express an engineered version of a PET-degrading enzyme [30].

Any processes based on microbial metabolism require nutrients for their activities, and plastics could be considered as a carbon source for certain microorganisms living in communities. Living and non-living 
cells can be used in sorption processes for pollutant removal from wastewater. The approaches can be classified as (i) metabolism dependent, or bioaccumulation, and (ii) metabolism independent, or passive biosorption [31].

\section{Past and Present Applications Involving Microalgae and Cyanobacteria}

Microalgae have been largely investigated for biotechnological applications in the last decades, especially to produce biofuels [32-34]. C. reinhardtii has been considered as a model microorganism for investigations of mechanisms related to microalgal physiology, and also as a platform for industrial biotechnology [26,35]. Cyanobacteria, prokaryotic microorganisms with oxygenic photosynthesis, have also been under close attention for utilizations based on the exploitation of the photosynthetic machinery. These Gram-negative bacteria have the capacity to convert solar energy, $\mathrm{CO}_{2}$, and water into chemical energy while releasing $\mathrm{O}_{2}$ into the atmosphere. Chlorophyll $a$ and phycobiliproteins are the primary photosynthetic pigments [36]. Some strains are able to fix $\mathrm{N}_{2}$ into ammonia. Synechococcus and Prochlorococcus are two examples of abundant cyanobacteria in seawater [37]. The outer and plasma membranes are two of the three membranes present in cyanobacteria, constituting the cell envelope and delimiting the periplasmic space. The third barrier is the thylakoid membrane system, localized inside the cell and containing the complexes involved in the photosynthetic electron transfer chain (e.g., photosystem I and photosystem II) [38,39]. Compared with other oxygenic photosynthetic organisms, cyanobacteria possess the highest solar energy capturing efficiency with corresponding adequate $\mathrm{CO}_{2}$-concentrating mechanisms and $\mathrm{CO}_{2}$ fixation. These prokaryotes have a long tradition and history of use as a source for human food and as a fertilizer in rice fields. They were also recognized early as an excellent source of proteins and vitamins, and therefore, they were used to produce health food products. Biologically active compounds with antiviral, antibacterial, antifungal, and anticancer activities can be derived from these photosynthetic microorganisms [40-45]. The role of cyanobacteria in the carbon cycle and for other nutrients (e.g., nitrogen) in different environments, their evolution, their adaptation to climate change, and issues related to some toxic blooms are also topics of investigation [37]. These are also able to produce biopolymers, such as polyhydroxyalkanoates (PHAs), and polyhydroxybutyrate (PHB) [46-49]. PHAs are polyesters, which accumulate in different microorganisms. They are recognized as alternatives for the most daily utilized plastics [50]. The physiological function of PHAs in the oxygen-producing photosynthetic prokaryotes is still not fully elucidated. PHB has been considered as an intracellular storage of carbon and energy in the model cyanobacterium Synechocystis sp. PCC 6803 [51,52]. In addition, cyanobacteria have great potential as a source of renewable and carbon-neutral chemicals, including biofertilizers and biofuels. Specifically, the native capacities to produce the energy carrier hydrogen $\left(\mathrm{H}_{2}\right)$ from solar energy and water were earlier recognized and have been discussed for a long time [53]. Large scale research initiatives are starting to address cyanobacteria as green cell factories. This can be exemplified by the so-called "CyanoFactory" approach, which includes, for example, the development of needed genetic tools, improved photosynthetic efficiencies, analyses and understanding of the modified metabolism with its further modeling, design and development of efficient photobioreactor systems, and biosafety aspects [54]. These photosynthetic micro-factories are increasingly considered important biocatalysts for the production of renewable and carbon-neutral chemicals and fuels from carbon dioxide and solar energy. As a proof-of-concept, strains have been engineered to produce numerous compounds. However, very few products show titers comparable to those achieved in heterotrophic organisms. One recent example is the systematic modular engineering of Synechocystis sp. PCC 6803, which resulted in a cumulative production titer of $4.8 \mathrm{~g}$ photosynthetic 1-butanol per liter with a maximal rate of $302 \mathrm{mg}$ per liter and day [55]. This is the highest productivity of 1-butanol from $\mathrm{CO}_{2}$ reported so far, and the strategy outlined can be seen as a blueprint for future systematic engineering in photosynthetic microorganisms. A combination of efficient genetic engineering and metabolic modeling will accelerate the development of solar chemical and fuel production in these bacteria. From a broader perspective, a recent review addressed diverse approaches to further enhance the production of all 
products derived from acetyl-CoA [56]. All these studies collectively demonstrate that cyanobacteria, as photosynthetic microorganisms, have a real potential to function as dedicated green cell factories for a truly carbon-neutral production of renewable chemicals and fuels. Moreover, with the use of advanced genetic engineering and synthetic biology in combination with improved modeling, they might be modified to address additional societal challenges, specifically for the bioremediation of plastics-based fragments, which is an important topic in the present review.

\section{Exposure to Micro- and Nanoplastics Accumulated in Aquatic Environments}

The scientific literature related to living organisms exposed to microplastics and nanoplastics is rapidly increasing. According to Scopus (22 November 2020), 752 document results appeared for the search item "'microplastics' and aquatic and environment". With the same tool, 130 documents resulted for "'nanoplastics' and aquatic and environment". Still, research efforts are strongly needed to comprehend the realities regarding the toxicity of these plastic fragments. A series of knowledge gaps have also been recently exposed. Relevant and important questions include the following [57]: What are the overall exposure concentrations from dietary and airborne sources? Are microplastics able to accumulate in the body? Do they become lodged or are they engulfed by cells? Finally, do polymer type and hydrophobicity influence toxicity? Data regarding the microplastic contamination of 201 edible animal species and some food products have been collected up until 2019 [10]. Mussels are one of the most investigated species on this topic $[4,10,58]$. The digestive tract of marine organisms contains high quantities of microplastics [59]. Nanoplastics generally give rise to bigger concerns than microplastics, and more data are needed to perform a full food safety risk assessment of seafood. These particles are intensively mentioned in recent comprehensive manuscripts [60-66]. Solely, microplastics smaller than $20 \mu \mathrm{m}$ should be able to enter organs, and those with a size of about $10 \mu \mathrm{m}$ can cross cell membranes of eukaryotic cells (e.g., mammalian cells) [63]. Injurious effects related to this, such as penetrating organs and causing systemic exposure, are still controversial.

Confirmations on the toxicological perspective of nanoplastics were shown on samples of human blood cells: adverse effects of proteins coated with nanoplastics have been observed [67]. Plastic packaging created to be utilized for beverages and foods can represent a source for particle uptake into the body $[68,69]$. The levels of nylon and PET particles released from teabag packaging into drinks are much higher than plastic loads previously reported in other foods [70]. Individuals with water intake through only bottled sources annually ingest a higher amount of microplastics than consumers of only tap water [71]. Due to the lack of validated methods, certified reference materials, and standardized analytical procedures, it is complicated to assess the exact exposure of humans to micro- and nanoplastics through food consumption [10]. It is important to consider an increased intake of micro- and nanoplastics in the future as a result of the degradation of plastics already released into aquatic environments [59].

\section{The Potential of Microalgae and Cyanobacteria for Plastics Biodegradation}

Towards bioremediation, the metabolism-dependent processes for biosorption involves generally two steps: (i) the attachment of the pollutant on the surface of the cell, or vice-versa, depending on the size ratio, and (ii) the active or passive transportation of the pollutant into the cell [31]. The biomass can be immobilized or combined with membrane separation in order to improve the uptake of plastic particles [31]. Biodegradation can be summarized in four essential steps, which have been described in detail in previous works [72-74].

(i) Bio-deterioration is the initiation of biodegradation, indicated by superficial degradation attacking mechanical and chemical properties of the macromolecular structure, generally through abiotic parameters (mechanical, light, thermal, and chemical), for example, air turbulences, sunlight, and atmospheric pollutants [73]. Soon after, a biofilm grows on the plastic particle and microbial communities produce extracellular polymeric substances, which enter the pores of the plastic and 
cause cracks. A probable release of acid compounds, like nitrous acid by chemolithotrophic bacteria, would weaken the structure further [72].

(ii) Bio-fragmentation mainly destabilizes long carbon chains, which microorganisms accomplish by enzymes called oxygenases (mono- and di-oxygenases) to form, for instance, alcohols, by adding oxygen to the carbon chain, or by hydrolases (such as proteases and lipases). It is supported by environmental influences like UV radiation, mechanical, and/or chemical factors [72,73].

(iii) Assimilation by microorganisms can only occur when specific carriers (e.g., receptors) are used to cross the cytoplasmic membrane [73]. Once inside, building blocks are oxidized via catabolic pathways (aerobic respiration, anaerobic respiration, and fermentation) for energy and biomass production.

(iv) Mineralization refers to complete degradation, as assimilation results in secondary metabolites by the biodegrading organism, remains that might be used by other organisms. The final products are oxidized metabolites $\left(\mathrm{CO}_{2}, \mathrm{~N}_{2}, \mathrm{CH}_{4}, \mathrm{H}_{2} \mathrm{O}\right)$ [73].

Degradation of plastic fragments via living photosynthetic microorganisms should be considered as a future strategy (Figure 1).

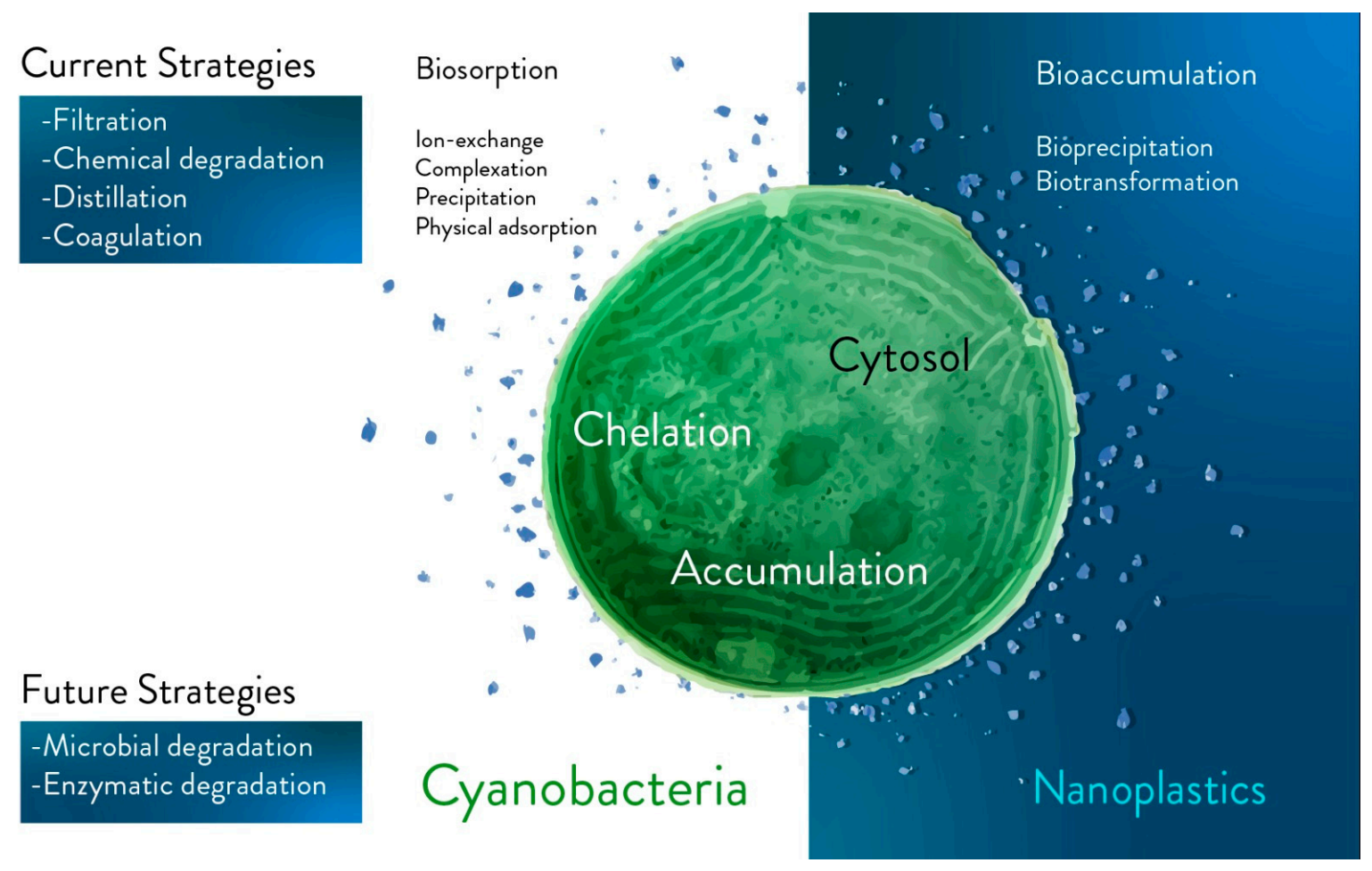

Figure 1. Main current and future strategies for plastics bioremediation. The main current (e.g., filtration, chemical degradation, distillation, and coagulation) and future (e.g., in vivo degradation via microorganisms, and enzyme-based degradation) strategies are separated into two different blocks in the figure. Future strategies are based on biological tools and potentially on in vivo approaches. Biosorption (e.g., ion-exchange, complexation, precipitation, and physical absorption), intracellular bioaccumulation (e.g., bioprecipitation and biotransformation) and extracellular mechanisms are approaches to be further investigated with the aim of capturing fragments of plastic comparable in size to photosynthetic microorganisms (e.g., the dimensions of nanoplastics and cyanobacteria).

The consideration of plastics as sources of nutrients for microorganisms depends on the presence of oxygen and the metabolic pathways of the species involved. Colonies of bacteria are present on the surface of most investigated plastic litter found on the surface of oceans or freshwater basins. Among them, cyanobacteria are included [75]. Bacteroidetes and cyanobacteria dominate in many plastics communities and may play an important role in the ecological process occurring in microbial films on plastics [75]. The performance of nanoplastic remediation in nature based on cyanobacteria 
has still not been taken into consideration. On the downside, the rates of degradation of conventional plastic by microorganisms are extremely low, even in optimized laboratory conditions [76]. On the upside, chemically sensitive polymers are more suitable for microbial growth [77]. We still lack information about the cyanobacterial potential for plastic degradation.

\section{Plastics Biodegradation via Photosynthetic Microorganisms in Freshwater and Marine Basins}

Cyanobacteria and green algae are a fundamental part of phytoplankton, organisms at the base of the trophic chain in freshwaters. They may have a role in plastic degradation $[29,30]$. The time scale of their action does not reduce the amount of plastic in a contaminated basin as quickly as desired. ROS formation has been a common response to nanoparticles, which affects lipids and proteins, eventually leading to the damage of the cytoplasmic membrane [23,24]. Furthermore, the existence of microplastics in groundwater has been confirmed, albeit in small amounts [78]. One example of the bioremediation of plastics in freshwater has recently been shown [79]. The researchers collected PE bags found in suburban water bodies (three sites along the same river in Chennai City, India) and isolated green algae, cyanobacteria, and diatoms. The most common organisms were Scenedesmus dimorphus, Anabaena spiroides, and Navicula pupula; they have been studied for their potency on the deterioration of PE [79]. The surfaces of LDPE sheets were found to be more readily colonized by the algae than HDPE sheets, with $A$. spiroides being the most efficient microorganism. While biological degradation of LDPE was observed for all three mentioned algae, $A$. spiroides caused a loss of $8.18 \%$ of mass per month on average (the test set being sheets of $1 \mathrm{~cm}^{2}$ of PE bags, held at $\sim 27^{\circ} \mathrm{C}$ ), followed by N. pupula at $4.4 \%$ loss of mass per month on average. Microorganisms with enhanced capacity to produce oxidative and ligninolytic enzymes are more efficient in the biodegradation of PE [80]. Due to the fact that cyanobacteria need light sources for survival, it is generally believed that degradation via these bacteria might be limited to surface-accessible particles [74]. In another study, two cyanobacterial species, Phormidium lucidum and Oscillatoria subbrevis (found in domestic sewage water) were investigated for their potential in the biodegradation of PE [81]. It is also assumed that cyanobacterial interaction enhances the surface hydrophilicity of PE by the formation of carbonyl, a key marker of biodegradation. PE strips $\left(1 \mathrm{~cm}^{2}\right.$, with $20 \mu \mathrm{m}$ thickness) treated with the aforementioned cyanobacteria had an increased carbonyl index, and the crystallinity of these strips decreased up to $62 \%$. Both algae utilized about 3 to $4 \%$ of the carbon present within a period of 6 weeks. A loss of weight of these pieces was reported to be $30 \%$ after 42 days [81]. Though the main focus of research regarding microplastics is on marine environments and the pollution of the oceans, some articles deal with plastic pollution of soil [82-84]. Microplastic particles, for example, PE beads, can be transported below the soil surface via earthworms and potentially reach groundwater [85]. The freshwater microalgae C. reinhardtii was investigated within solutions of PS microplastic powder at concentrations of 0 to $100 \mathrm{mg} / \mathrm{L}$ in ultrapure water [86]. The authors observed decreased chlorophyll $a$ fluorescence yields and diminished photosynthetic activity, which started to recover after approximately 10 days [86]. Plastic particles were attached to the surface of this microalgae, damaging the cell membrane. On the other hand, this might also indicate a potential cell-based approach to reduce PS concentration in the water. This hints at a tolerance of PS by photosynthetic bacteria, such as cyanobacteria. In another study, the effects of plastic intake by Daphnia magna were investigated [87]. The main diet of this zooplankton is based on green algae, which attach to plastic particles and thus, microplastics are present in its digestive system. Over a duration of three weeks, D. magna were exposed to microplastics in moderately hard water. The researchers found that an organism of $D$. magna accumulated after 5 days an average amount of $0.44,1.56$ and 1.75 microplastic particles for concentrations of 25, 50, and $100 \mathrm{mg} / \mathrm{L}$ of microplastics in the solution, respectively. These numbers increased about eight-fold after 21 days. Interestingly, the researchers did not observe a significant alteration of survival and reproduction rates of D. magna [87]. 
A complete study of the biodegradation of a polymer at sea must combine several monitoring parameters (e.g., the research network initiative, "Polymers \& Oceans"), and especially be confirmed in the field with experiments in situ [74]. Among the microorganisms colonizing plastic fragments, cyanobacteria are most certainly present [74]. An outlook on the possible degradation of floating fragments is illustrated in Figure 2. A recent study in seawater showed that plastic can stimulate the activity of heterotrophic microbes, due to the release of dissolved organic carbon [88].

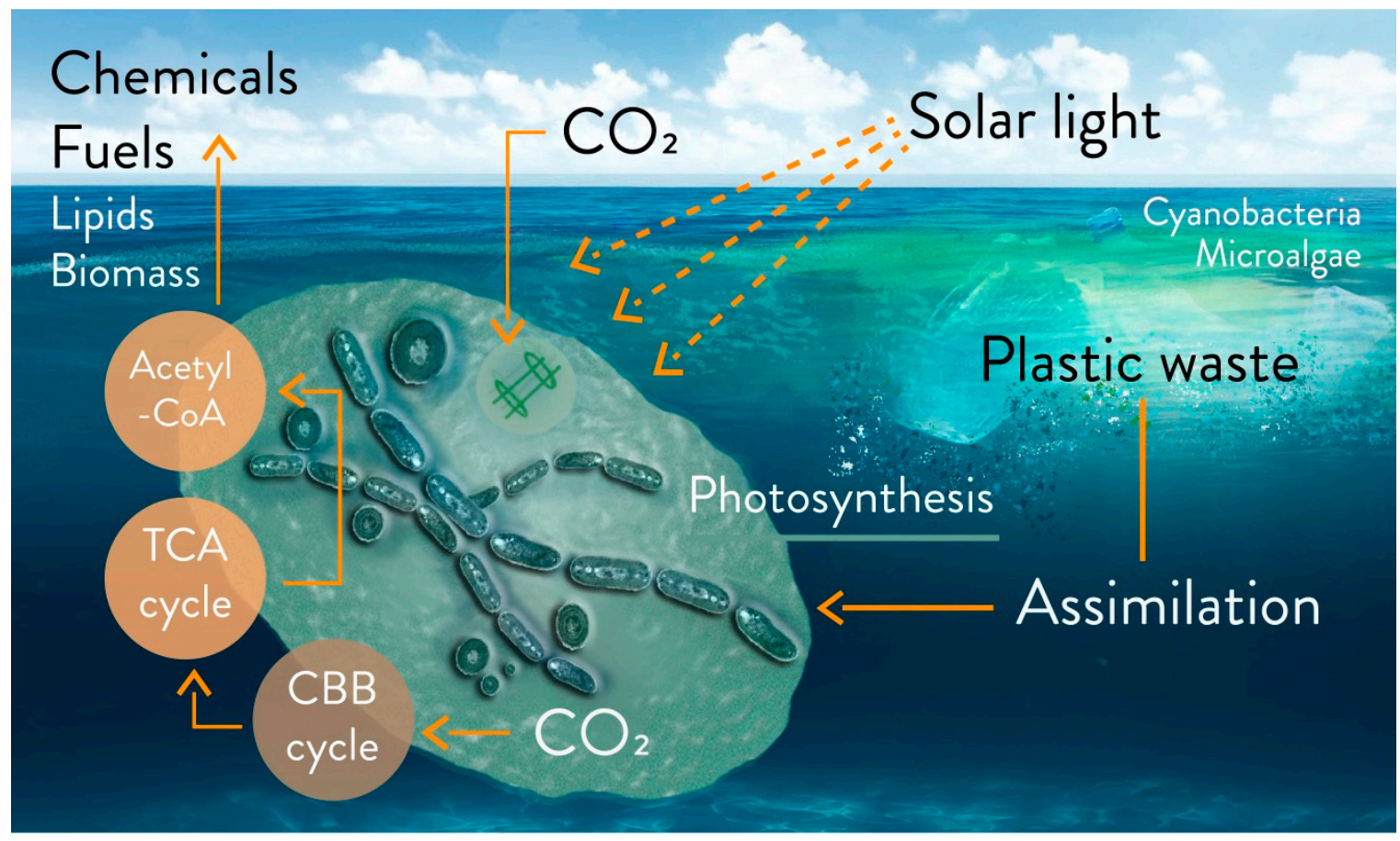

Figure 2. Outlook on the possible biodegradation and bioremediation of floating plastic fragments from accumulated plastic waste in marine water with microalgae and cyanobacteria, via metabolic uptake or biosorption. Biofuel (e.g., $\mathrm{H}_{2}$ and isobutanol), biochemicals, lipids, and biomass can be products based on photosynthetic microbial growth on floating plastic wastes. Engineered strains can be utilized on a laboratory scale, utilizing macro-, micro- and nanoplastics as sources of carbons. CBB cycle: Calvin-Benson-Bassham cycle; TCA cycle: tricarboxylic acid cycle; acetyl-CoA: acetyl coenzyme A.

Several plastics of purely petrochemical origin are not biodegradable; consequently, biodegradable plastics were developed, for example, poly(lactic acid) (PLA) and poly( $\varepsilon$-caprolactone) (PCL). Some potential enzymes that might play a role in the biodegradation of these compounds include PHA-, PHB-, PLA- and PCL-depolymerases, esterases, proteinases, cutinases, ureases, and dehydratases [89]. The finding of cold-adapted bacterial strains with lipase activity is potentially important in view of the biodegradation process [90]. Furthermore, it can be expected that other enzymes secreted by bacteria isolated from cold environments will show biodegradable activity. Extracellular lipase activity was also detected in microbial strains isolated from Arctic sea ice of the Canada Basin [91]. These were identified as belonging to heterotrophic microorganisms from the genera Colwellia, Marinomonas, Pseudoalteromonas, Pseudomonas, and Shewanella. A recent review on microbial ecotoxicology contains precise observations on the interplay between pollutants and microbial communities, related to plastic pollution in the oceans [74]. Microbial ecotoxicology focuses on the mutual influence of pollutants and microbial communities. Plastic pollutants in the ocean, for instance, are affected by various communities, depending if the debris is floating or has sunk to the seafloor. Cyanobacteria of the genera Phormidium and Rivularia are most certainly found in biofilms near the water surface, while the dominant microbiomes of the seafloor seem to be Bacteroidetes (Flavobacteriaceae) and Proteobacteria (Rhodobacteraceae and Alcanivoracaceae)—information on the composition of microbial communities 
from plastic at the seafloor is still sparse [74]. Biofilm growing on plastic fragments, able to support the additional weight, shows differences in bacterial distributions between non-biodegradable and biodegradable plastics. While many factors influence the composition of the biofilm, studies in the North Pacific indicate that biogeographic origins play a major role, more important than the polymer type [74]. Complex microbial communities, rather than single species, are necessary to degrade plastic. Still, a representative test of biodegradation in oceans is missing, as current standards propose measurements of $\mathrm{CO}_{2}$ emissions that might be misleading; additional methods should be applied, and guidelines formulated [74].

Further research of native pathways and related enzymes is necessary for the applicability of cyanobacteria on this topic. Species identified with roles in plastic degradation (e.g., Pseudomonas, Streptomyces, Corynebacterium, Arthrobacter, Micrococcus, and Rhodococcus) give information for key metabolic routes. These are the foundations to state any native potential of photosynthetic microorganisms. The diversity of synthetic polymers in commerce results in very heterogeneous metabolic pathways of biodegradation. In these regards, the focus should be channeled into model compounds (e.g., PE, PET, PS, and PHA) for conventional and biodegradable plastics [74]. Metabolic pathways directly involved in the degradation of, for example, PE, PET, PS, and PHAs have been identified [74]. However, PE is, so far, difficult to degrade biologically, due to its balanced charges in the long chains of carbons and hydrogen. The possible transformation via the tricarboxylic acid (TCA) cycle, in the case of specific release products by capable wild-type or engineered microorganisms, also generates adenosine triphosphate (ATP), which is a key factor for biomass production and cellular growth [74]. Due to the difficulty of dealing with natural conditions, and based on the information from previously published investigations, we suggest that the initial studies regarding metabolic engineered cyanobacteria for plastic biodegradation should be performed using a culture-based approach $[79,81]$.

\section{Heterologous Enzymes with Potential for In Vitro Approaches in Plastic Bioremediation}

Enzymes normally operate in mild conditions and they possess high selectivity towards natural target compounds, which allow them to be preferred over, for example, metal catalysts. In order to act on specific substrates, enzymes have to recognize the reagents as target compounds; that is not the routine in industrially relevant reactions where chemicals contain non-natural modifications. In polymer chemistry, enzymes have been used both in the synthesis and in the hydrolysis of polymers to produce specific substitutions or to improve functionalization, respectively [92-94]. Different features of the two components, the polymer and the enzyme, must be considered in order to improve the specificity of the reaction. Polymeric chains present at the surface can be recognized by enzymes and functional groups can be formed. Degradable polymers can show differences in biodegradability, depending on the enzymes present to recognize them as targets. Enzymes can act differently on specific polymers [95]. Polymers have shown the ability to be biodegraded only when the polymer chain is interrupted by hetero-atoms, such as oxygen or nitrogen, or by the presence of a CC double bond. In order to start the biodegradation of the material, extracellular enzymes, constitutively expressed or induced by the presence of the material, must begin the fragmentation of the polymer in its building blocks. These processes have been reported to be affected by different parameters of the polymer, such as crystallinity, viscosity, and melting point $[96,97]$. Biodegradability can be described as an event that takes place through the action of enzymes and/or chemical decomposition associated with living organisms or their secretion products, with the aid of abiotic reactions, such as photodegradation, oxidation, and hydrolysis [98]. Enzyme expression can be induced by the presence of polymers to hydrolyze specific bonds. Further modification and assimilation of the building blocks can lead to a complete degradation and removal of the polymer by specific microorganisms. Enzymatic degradation of fossil-based plastics has been thoroughly studied both at academic and industrial levels. Different studies have analyzed the possibility of wild-type enzymes derived from different origins, and designer enzymes to specifically adsorb and attack certain man-made polymeric compounds [99-102]. Modification of the 3D structure of the enzyme is usually needed 
to improve their activity, stability, and specificity [103]. Due to the ability of cyanobacteria to be used as cell factories, these microorganisms may be used to produce enzymes that can specifically degrade polymeric structures, in order to reduce the presence of micro- and nanoplastics in the environment. In particular, the hydrolase PETase from Ideonella sakaiensis was thoroughly studied for in vitro PET hydrolysis [102]. A recent study described a significant improvement of PET degradation in laboratory conditions: over 90\% of PET was degraded in just $10 \mathrm{~h}$ [101]. The enzyme PETase and its variants were previously expressed from different hosts (such as Escherichia coli and Bacillus subtilis). Interestingly, the improved variant PETase ${ }^{\mathrm{R} 280 \mathrm{~A}}$ was recombinantly expressed and secreted by the marine photosynthetic single-celled diatom P. tricornutum [30]. This diatom has high potential for biotechnological applications due to its ability to combine the benefits of a photosynthetic organism and the rapid growth under $\mathrm{CO}_{2}$ in a saltwater-based environment [104]. Specifically, in the abovementioned work, the authors used a nitrate inducible promoter for the expression of the enzyme [30]. The gene was modified to contain the region, encoding the signal peptide of the P. tricornutum alkaline phosphatase. This is the first example to our knowledge of the use of photosynthetic organisms to be used as expression hosts for the production of plastic-degrading enzymes [30]. More information on plastic degradation by wild-type enzymes derived from microalgae and cyanobacteria are needed, and novel discoveries of this activity could lead to interesting results and applications of these fascinating microorganisms. Further studies on the expression of the wild-type enzyme PETase in photosynthetic microorganisms were also carried out on two strains of C. reinhardtii (i.e., CC-124 and CC-503) due to faster growth compared with $P$. tricornutum. The $C$. reinhardtii strains were used to test the ability to express the I. sakaiensis PETase. The strain CC-124 showed an ability to express the enzyme and the activity of its cell extract was tested on PET samples for up to 4 weeks [29].

\section{Conclusions}

Environmental contamination of microplastics and nanoplastics have become a frequently documented topic in the public community. Many landscapes have negatively changed in appearance due to the accumulation of plastics. Concerns through scientific publications have strongly increased since at least 2016. Timely actions can prevent or remediate the presence of plastics in nature, resulting in environmental and economic benefits. Cyanobacteria are photosynthetic bacteria that are often colonizing the buoyant microplastics in marine and freshwater. Plastic bioremediation based on microorganisms is yet poorly studied, and not perfectly matching the time required for the desired fast environmental recovery from plastic pollution. Still, more efforts for a deeper investigation should be made, also to increase the limited available data in this context. In vitro approaches with isolated enzymes have been addressed over the years. In vivo approaches of bioremediation based on immobilized cyanobacteria, in micro- and nanoplastics-contaminated sea- and freshwater should be further investigated. Synthetic polymers can be mentioned as a family of macromolecules, having different members with a higher or lower degree of biodegradability. Much attention is currently focused on polyesters, due to the similarity in their structure to natural compounds (e.g., cutin) and their ability to be biodegraded by enzymes. Microorganisms can evolve to adapt to different nutritional sources. However, little is still known regarding the biodegradation of polyolefins. The latter do not contain heteroatoms in their structure and for this reason, these show a low degree of biodegradation. The differences between biodegradation and biomineralization should be taken into account for the identification of the ability to recycle building blocks, or to use the polymeric materials (e.g., plastic waste at the surface of freshwater or marine basins) as feedstocks for microorganisms (e.g., photosynthetic microorganisms) to produce biomass.

Author Contributions: G.D.B., D.F., A.B. searched in literature, collected information and wrote the review; P.L. supervised, gave suggestions and edited the text. All authors have read and agreed to the published version of the manuscript.

Funding: This review received no external funding. 
Acknowledgments: Giovanni Barone (Polytechnic University of Milan, Department of Design) is acknowledged for his support to realize the figures. This paper is published with the help of TU Graz Open Access Publishing Fund. Antonino Biundo gratefully acknowledges the financial support from the Interuniversity Consortium for Biotechnology (CIB), Italy. The authors would like to express their gratitude towards the anonymous reviewers for their input, which greatly improved the quality of this manuscript.

Conflicts of Interest: The authors declare no conflict of interest.

\section{References}

1. Min, K.; Cuiffi, J.D.; Mathers, R.T. Ranking environmental degradation trends of plastic marine debris based on physical properties and molecular structure. Nat. Commun. 2020, 11, 1-11. [CrossRef] [PubMed]

2. Plastics Europe. Plastics-The Facts 2019. An Analysis of European Plastics Production, Demand and Waste Data. Available online: https://www.plasticseurope.org/en (accessed on 22 November 2020).

3. Steensgaard, I.M.; Syberg, K.; Rist, S.; Hartmann, N.B.; Boldrin, A.; Hansen, S.F. From macro- to microplasticsAnalysis of EU regulation along the life cycle of plastic bags. Environ. Pollut. 2017, 224, 289-299. [CrossRef] [PubMed]

4. EFSA Panel on Contaminants in the Food Chain (CONTAM). Presence of microplastics and nanoplastics in food, with particular focus on seafood. EFSA J. 2016, 14, 30. [CrossRef]

5. Barnes, D.K.; Galgani, F.; Thompson, R.C.; Barlaz, M. Accumulation and fragmentation of plastic debris in global environments. Philos. Trans. R. Soc. B Biol. Sci. 2009, 364, 1985-1998. [CrossRef] [PubMed]

6. Zalasiewicz, J.; Waters, C.N.; Sul, J.A.I.D.; Corcoran, P.L.; Barnosky, A.D.; Cearreta, A.; Edgeworth, M.; Gałuszka, A.; Jeandel, C.; Leinfelder, R.; et al. The geological cycle of plastics and their use as a stratigraphic indicator of the Anthropocene. Anthropocene 2016, 13, 4-17. [CrossRef]

7. Zubris, K.A.V.; Richards, B.K. Synthetic fibers as an indicator of land application of sludge. Environ. Pollut. 2005, 138, 201-211. [CrossRef]

8. Dris, R.; Gasperi, J.; Mirande, C.; Mandin, C.; Guerrouache, M.; Langlois, V.; Tassin, B. A first overview of textile fibers, including microplastics, in indoor and outdoor environments. Environ. Pollut. 2017, 221, 453-458. [CrossRef]

9. Jambeck, J.R.; Geyer, R.; Wilcox, C.; Siegler, T.R.; Perryman, M.; Andrady, A.; Narayan, R.; Law, K.L. Plastic waste inputs from land into the ocean. Science 2015, 347, 768-771. [CrossRef]

10. Toussaint, B.; Raffael, B.; Angers-Loustau, A.; Gilliland, D.; Kestens, V.; Petrillo, M.; Rio-Echevarria, I.M.; Eede, G.V.D. Review of micro- and nanoplastic contamination in the food chain. Food Addit. Contam. Part A 2019, 36, 639-673. [CrossRef]

11. Tang, K.H.D. Ecotoxicological Impacts of Micro and Nanoplastics on Marine Fauna. Exam. Mar. Biol. Oceanogr. 2020, 3. [CrossRef]

12. Ta, A.T.; Babel, S. Microplastic contamination on the lower Chao Phraya: Abundance, characteristic and interaction with heavy metals. Chemosphere 2020, 257, 127234. [CrossRef] [PubMed]

13. Corti, A.; Vinciguerra, V.; Iannilli, V.; Pietrelli, L.; Manariti, A.; Bianchi, S.; Petri, A.; Cifelli, M.; Domenici, V.; Castelvetro, V. Thorough Multianalytical Characterization and Quantification of Micro- and Nanoplastics from Bracciano Lake's Sediments. Sustainability 2020, 12, 878. [CrossRef]

14. Anderson, P.J.; Warrack, S.; Langen, V.; Challis, J.K.; Hanson, M.L.; Rennie, M.D. Microplastic contamination in Lake Winnipeg, Canada. Environ. Pollut. 2017, 225, 223-231. [CrossRef] [PubMed]

15. Dong, M.; Luo, Z.; Jiang, Q.; Xing, X.; Zhang, Q.; Sun, Y. The rapid increases in microplastics in urban lake sediments. Sci. Rep. 2020, 10, 1-10. [CrossRef]

16. Ásmundsdóttir, Á.M.; Gomiero, A.; Øysæd, K.B. Microplastics and Nanoplastics Occurrence and Composition in Drinking Water from Akureyri Urban Area, Iceland. In Proceedings of the 2nd International Conference on Microplastic Pollution in the Mediterranean Sea, Capri, Italy, 15-18 September 2019; Springer: Cham, Switzerland, 2020; pp. 106-111. [CrossRef]

17. Zhang, M.; Li, J.; Ding, H.; Ding, J.; Jiang, F.; Ding, N.X.; Sun, C. Distribution Characteristics and Influencing Factors of Microplastics in Urban Tap Water and Water Sources in Qingdao, China. Anal. Lett. 2019, 53, 1312-1327. [CrossRef] 
18. Tong, H.; Jiang, Q.; Hu, X.; Zhong, X. Occurrence and identification of microplastics in tap water from China. Chemosphere 2020, 252, 126493. [CrossRef]

19. Lam, T.W.; Ho, H.T.; Ma, A.T.; Fok, L. Microplastic Contamination of Surface Water-Sourced Tap Water in Hong Kong-A Preliminary Study. Appl. Sci. 2020, 10, 3463. [CrossRef]

20. Wagner, M.; Scherer, C.; Alvarez-Muñoz, D.; Brennholt, N.; Bourrain, X.; Buchinger, S.; Fries, E.; Grosbois, C.; Klasmeier, J.; Marti, T.; et al. Microplastics in freshwater ecosystems: What we know and what we need to know. Environ. Sci. Eur. 2014, 26, 1-9. [CrossRef]

21. Vallero, D.A.; Gunsch, C.K. Applications and Implications of Emerging Biotechnologies in Environmental Engineering. J. Environ. Eng. 2020, 146, 03120005. [CrossRef]

22. Singh, S.; Kumar, V.; Datta, S.; Dhanjal, D.S.; Sharma, K.; Samuel, J.; Singh, J. Current advancement and future prospect of biosorbents for bioremediation. Sci. Total Environ. 2020, 709, 135895. [CrossRef]

23. Bhattacharya, P.; Lin, S.; Turner, J.P.; Ke, P.C. Physical Adsorption of Charged Plastic Nanoparticles Affects Algal Photosynthesis. J. Phys. Chem. C 2010, 114, 16556-16561. [CrossRef]

24. Nolte, T.M.; Hartmann, N.B.; Kleijn, J.M.; Garnæs, J.; Van De Meent, D.; Hendriks, A.J.; Baun, A. The toxicity of plastic nanoparticles to green algae as influenced by surface modification, medium hardness and cellular adsorption. Aquat. Toxicol. 2017, 183, 11-20. [CrossRef] [PubMed]

25. González-Pleiter, M.; Tamayo-Belda, M.; Pulido-Reyes, G.; Amariei, G.; Leganés, F.; Rosal, R.; Fernández-Piñas, F. Secondary nanoplastics released from a biodegradable microplastic severely impact freshwater environments. Environ. Sci. Nano 2019, 6, 1382-1392. [CrossRef]

26. Tran, N.T.; Kaldenhoff, R. Achievements and challenges of genetic engineering of the model green alga Chlamydomonas reinhardtii. Algal Res. 2020, 50, 101986. [CrossRef]

27. Harris, E.H. The Chlamydomonas Sourcebook. Introduction to Chlamydomonas and Its Laboratory Use, 2nd ed.; Academic Press: Oxford, UK, 2008; ISBN 9780123708748.

28. Eberhard, S.; Valuchova, S.; Ravat, J.; Fulneček, J.; Jolivet, P.; Bujaldon, S.; Lemaire, S.D.; Wollman, F.-A.; Teixeira, M.T.; Riha, K.; et al. Molecular characterization of Chlamydomonas reinhardtii telomeres and telomerase mutants. Life Sci. Alliance 2019, 2, 201900315. [CrossRef]

29. Kim, J.W.; Park, S.-B.; Tran, Q.-G.; Cho, D.-H.; Choi, D.-Y.; Lee, Y.J.; Kim, H.-S. Functional expression of polyethylene terephthalate-degrading enzyme (PETase) in green microalgae. Microb. Cell Fact. 2020, 19, 1-9. [CrossRef]

30. Moog, D.; Schmitt, J.; Senger, J.; Zarzycki, J.; Rexer, K.-H.; Linne, U.; Erb, T.; Maier, U.G. Using a marine microalga as a chassis for polyethylene terephthalate (PET) degradation. Microb. Cell Fact. 2019, 18, 1-15. [CrossRef]

31. Wenten, I.G.; Khoiruddin, K.; Harimawan, A.; Ting, Y.P.; Boopathy, R. Membrane Biosorption: Recent Advances and Challenges. Curr. Pollut. Rep. 2020, 6, 152-172. [CrossRef]

32. Shanmugam, S.; Hari, A.; Kumar, D.; Rajendran, K.; Mathimani, T.; Atabani, A.; Brindhadevi, K.; Pugazhendhi, A. Recent developments and strategies in genome engineering and integrated fermentation approaches for biobutanol production from microalgae. Fuel 2021, 285, 119052. [CrossRef]

33. Brindhadevi, K.; Mathimani, T.; Rene, E.R.; Shanmugam, S.; Chi, N.T.L.; Pugazhendhi, A. Impact of cultivation conditions on the biomass and lipid in microalgae with an emphasis on biodiesel. Fuel 2021, 284, 284. [CrossRef]

34. Correa, D.F.; Beyer, H.L.; Possingham, H.P.; Fargione, J.E.; Hill, J.D.; Schenk, P.M. Microalgal biofuel production at national scales: Reducing conflicts with agricultural lands and biodiversity within countries. Energy 2021, 215. [CrossRef]

35. Perozeni, F.; Cazzaniga, S.; Baier, T.; Zanoni, F.; Zoccatelli, G.; Lauersen, K.J.; Wobbe, L.; Ballottari, M. Turning a green alga red: Engineering astaxanthin biosynthesis by intragenic pseudogene revival in Chlamydomonas reinhardtii. Plant Biotechnol. J. 2020, 18, 2053-2067. [CrossRef] [PubMed]

36. Waterbury, J.B. The Cyanobacteria-Isolation, Purification and Identification. Prokaryotes 2006, 4, $1053-1073$. [CrossRef]

37. Bullerjahn, G.S.; Post, A.F. Physiology and molecular biology of aquatic cyanobacteria. Front. Microbiol. 2014, 5, 359. [CrossRef] 
38. Rengstl, B.; Oster, U.; Stengel, A.; Nickelsen, J. An Intermediate Membrane Subfraction in Cyanobacteria Is Involved in an Assembly Network for Photosystem II Biogenesis. J. Biol. Chem. 2011, 286, 21944-21951. [CrossRef]

39. Vermaas, W.F.J. Encyclopedia of Life Sciences; Nature Publishing Group: London, UK, 2001; pp. $245-251$.

40. Angermayr, S.A.; Rovira, A.G.; Hellingwerf, K. Metabolic engineering of cyanobacteria for the synthesis of commodity products. Trends Biotechnol. 2015, 33, 352-361. [CrossRef]

41. Zahra, Z.; Choo, D.H.; Lee, H.; Parveen, A. Cyanobacteria: Review of Current Potentials and Applications. Environments 2020, 7, 13. [CrossRef]

42. Carroll, A.L.; Case, A.E.; Zhang, A.; Atsumi, S. Metabolic engineering tools in model cyanobacteria. Metab. Eng. 2018, 50, 47-56. [CrossRef]

43. Zhou, J.; Meng, H.; Zhang, W.; Li, Y. Production of Industrial Chemicals from $\mathrm{CO}_{2}$ by Engineering Cyanobacteria. Adv. Exp. Med. Biol. 2018, 1080, 97-116. [CrossRef]

44. Ni, J.; Tao, F.; Xu, P.; Yang, C. Engineering Cyanobacteria for Photosynthetic Production of C3 Platform Chemicals and Terpenoids from $\mathrm{CO}_{2}$. Results Probl. Cell Differ. 2018, 1080, 239-259. [CrossRef]

45. Behler, J.; Vijay, D.; Hess, W.R.; Akhtar, M.K. CRISPR-Based Technologies for Metabolic Engineering in Cyanobacteria. Trends Biotechnol. 2018, 36, 996-1010. [CrossRef]

46. Koch, M.; Berendzen, K.W.; Forchhammer, K. On the Role and Production of Polyhydroxybutyrate (PHB) in the Cyanobacterium Synechocystis sp. PCC 6803. Life 2020, 10, 47. [CrossRef] [PubMed]

47. Ansari, S.; Fatma, T. Cyanobacterial Polyhydroxybutyrate (PHB): Screening, Optimization and Characterization. PLoS ONE 2016, 11, e0158168. [CrossRef] [PubMed]

48. Markl, E.; Grünbichler, H.; Lackner, M. Cyanobacteria for PHB Bioplastics Production: A Review. In Algae; IntechOpen: London, UK, 2019.

49. Miyake, M.; Takase, K.; Narato, M.; Khatipov, E.-A.; Schnackenberg, J.; Shirai, M.; Kurane, R.; Asada, Y. Polyhydroxybutyrate Production from Carbon Dioxide by Cyanobacteria. Appl. Biochem. Biotechnol. 2000, 991-1002. [CrossRef]

50. Madison, L.L.; Huisman, G.W. Metabolic Engineering of Poly(3-Hydroxyalkanoates): From DNA to Plastic. Microbiol. Mol. Biol. Rev. 1999, 63, 21-53. [CrossRef] [PubMed]

51. Klotz, A.; Georg, J.; Bučinská, L.; Watanabe, S.; Reimann, V.; Januszewski, W.; Sobotka, R.; Jendrossek, D.; Hess, W.R.; Forchhammer, K. Awakening of a Dormant Cyanobacterium from Nitrogen Chlorosis Reveals a Genetically Determined Program. Curr. Biol. 2016, 26, 2862-2872. [CrossRef]

52. Wu, G.; Wu, Q.; Shen, Z. Accumulation of poly- $\beta$-hydroxybutyrate in cyanobacterium Synechocystis sp. PCC6803. Bioresour. Technol. 2001, 76, 85-90. [CrossRef]

53. Khetkorn, W.; Rastogi, R.P.; Incharoensakdi, A.; Lindblad, P.; Madamwar, D.; Pandey, A.; Larroche, C. Microalgal hydrogen production-A review. Bioresour. Technol. 2017, 243, 1194-1206. [CrossRef]

54. Lindblad, P.; Fuente, D.; Borbe, F.; Cicchi, B.; Conejero, J.A.; Couto, N.; Čelešnik, H.; Diano, M.M.; Dolinar, M.; Esposito, S.; et al. CyanoFactory, a European consortium to develop technologies needed to advance cyanobacteria as chassis for production of chemicals and fuels. Algal Res. 2019, 41, 101510. [CrossRef]

55. Liu, X.; Miao, R.; Lindberg, P.; Lindblad, P. Modular engineering for efficient photosynthetic biosynthesis of 1-butanol from $\mathrm{CO}_{2}$ in cyanobacteria. Energy Environ. Sci. 2019, 12, 2765-2777. [CrossRef]

56. Miao, R.; Xie, H.; Liu, X.; Lindberg, P.; Lindblad, P. Current processes and future challenges of photoautotrophic production of acetyl-CoA-derived solar fuels and chemicals in cyanobacteria. Curr. Opin. Chem. Biol. 2020, 59, 69-76. [CrossRef] [PubMed]

57. Wright, S.L.; Kelly, F.J. Plastic and Human Health: A Micro Issue? Environ. Sci. Technol. 2017, 51, $6634-6647$. [CrossRef] [PubMed]

58. Smith, M.; Love, D.C.; Rochman, C.M.; Neff, R. Microplastics in Seafood and the Implications for Human Health. Curr. Environ. Health Rep. 2018, 5, 375-386. [CrossRef] [PubMed]

59. Lusher, A.; Hollman, P.; Mendoza-Hill, J. Microplastics in Fisheries and Aquaculture: Status of Knowledge on Their Occurrence and Implications for Aquatic Organisms and Food Safety; FAO Fisheries and Aquaculture Technical paper; Food and Agriculture Organization of the United Nations: Rome, Italy, 2017; p. 615.

60. Yong, C.Q.Y.; Valiyaveettil, S.; Tang, B.L. Toxicity of Microplastics and Nanoplastics in Mammalian Systems. Int. J. Environ. Res. Public Health 2020, 17, 1509. [CrossRef] [PubMed] 
61. Rubio, L.; Marcos, R.; Hernández, A. Potential adverse health effects of ingested micro- and nanoplastics on humans. Lessons learned from in vivo and in vitro mammalian models. J. Toxicol. Environ. Health Part B 2019, 23, 51-68. [CrossRef]

62. Alexy, P.; Anklam, E.; Emans, T.; Furfari, A.; Galgani, F.; Hanke, G.; Koelmans, A.; Pant, R.; Saveyn, H.; Kluettgen, B.S. Managing the analytical challenges related to micro- and nanoplastics in the environment and food: Filling the knowledge gaps. Food Addit. Contam. Part A 2019, 37, 1-10. [CrossRef]

63. Campanale, C.; Massarelli, C.; Savino, I.; Locaputo, V.; Uricchio, V.F. A Detailed Review Study on Potential Effects of Microplastics and Additives of Concern on Human Health. Int. J. Environ. Res. Public Health 2020, 17, 1212. [CrossRef] [PubMed]

64. Barboza, L.G.A.; Vethaak, A.D.; Lavorante, B.R.; Lundebye, A.-K.; Guilhermino, L. Marine microplastic debris: An emerging issue for food security, food safety and human health. Mar. Pollut. Bull. 2018, 133, 336-348. [CrossRef]

65. Hantoro, I.; Löhr, A.J.; Van Belleghem, F.G.A.J.; Widianarko, B.; Ragas, A.M.J. Microplastics in coastal areas and seafood: Implications for food safety. Food Addit. Contam. Part A 2019, 36, 674-711. [CrossRef]

66. Rist, S.; Almroth, B.M.C.; Hartmann, N.B.; Karlsson, T. A critical perspective on early communications concerning human health aspects of microplastics. Sci. Total Environ. 2018, 626, 720-726. [CrossRef]

67. Gopinath, P.M.; Saranya, V.; Vijayakumar, S.; Meera, M.M.; Ruprekha, S.; Kunal, R.; Pranay, A.; Thomas, J.; Mukherjee, A.; Chandrasekaran, N. Assessment on interactive prospectives of nanoplastics with plasma proteins and the toxicological impacts of virgin, coronated and environmentally released-nanoplastics. Sci. Rep. 2019, 9, 1-15. [CrossRef] [PubMed]

68. Sobhani, Z.; Lei, Y.; Tang, Y.; Wu, L.; Zhang, X.; Naidu, R.; Megharaj, M.; Fang, C. Microplastics generated when opening plastic packaging. Sci. Rep. 2020, 10,1-7. [CrossRef]

69. Shruti, V.; Pérez-Guevara, F.; Elizalde-Martínez, I.; Kutralam-Muniasamy, G. First study of its kind on the microplastic contamination of soft drinks, cold tea and energy drinks-Future research and environmental considerations. Sci. Total Environ. 2020, 726, 138580. [CrossRef]

70. Hernandez, L.M.; Xu, E.G.; Larsson, H.C.E.; Tahara, R.; Maisuria, V.B.; Tufenkji, N. Plastic Teabags Release Billions of Microparticles and Nanoparticles into Tea. Environ. Sci. Technol. 2019, 53, 12300-12310. [CrossRef] [PubMed]

71. Cox, K.D.; Covernton, G.A.; Davies, H.L.; Dower, J.F.; Juanes, F.; Dudas, S.E. Human Consumption of Microplastics. Environ. Sci. Technol. 2019, 53, 7068-7074. [CrossRef] [PubMed]

72. Dussud, C.; Ghiglione, J.F. Bacterial Degradation of Synthetic Plastics. CIESM Workshop Monogr. 2014, 46, $43-48$.

73. Lucas, N.; Bienaime, C.; Belloy, C.; Queneudec, M.; Silvestre, F.; Nava-Saucedo, J.-E. Polymer biodegradation: Mechanisms and estimation techniques-A review. Chemosphere 2008, 73, 429-442. [CrossRef]

74. Jacquin, J.; Cheng, J.; Odobel, C.; Pandin, C.; Conan, P.; Pujo-Pay, M.; Barbe, V.; Meistertzheim, A.-L.; Ghiglione, J.-F. Microbial Ecotoxicology of Marine Plastic Debris: A Review on Colonization and Biodegradation by the "Plastisphere". Front. Microbiol. 2019, 10, 865. [CrossRef]

75. Oberbeckmann, S.; Loeder, M.G.; Gerdts, G.; Osborn, A.M. Spatial and seasonal variation in diversity and structure of microbial biofilms on marine plastics in Northern European waters. FEMS Microbiol. Ecol. 2014, 90, 478-492. [CrossRef]

76. Krueger, M.C.; Harms, H.; Schlosser, D. Prospects for microbiological solutions to environmental pollution with plastics. Appl. Microbiol. Biotechnol. 2015, 99, 8857-8874. [CrossRef]

77. Pathak, V.M. Navneet Review on the current status of polymer degradation: A microbial approach. Bioresour. Bioprocess. 2017, 4, 15. [CrossRef]

78. Mintenig, S.M.; Löder, M.G.J.; Primpke, S.; Gerdts, G. Low numbers of microplastics detected in drinking water from ground water sources. Sci. Total Environ. 2019, 648, 631-635. [CrossRef] [PubMed]

79. Kumar, R.V.; Kanna, G.R.; Elumalai, S. Biodegradation of Polyethylene by Green Photosynthetic Microalgae. J. Bioremed. Biodegrad. 2017, 8, 1-8. [CrossRef]

80. Nayak, P.; Tiwari, A. Biodegradation of polythene and plastic by the help of microbial tools: A recent approach. Int. J. Biomed. Adv. Res. 2011, 2, 344-355. [CrossRef] 
81. Sarmah, P.; Rout, J. Efficient biodegradation of low-density polyethylene by cyanobacteria isolated from submerged polyethylene surface in domestic sewage water. Environ. Sci. Pollut. Res. 2018, 25, 33508-33520. [CrossRef] [PubMed]

82. Sarker, A.; Deepo, D.M.; Nandi, R.; Rana, J.; Islam, S.; Rahman, S.; Hossain, M.N.; Islam, S.; Baroi, A.; Hwang, J.-I. A review of microplastics pollution in the soil and terrestrial ecosystems: A global and Bangladesh perspective. Sci. Total Environ. 2020, 733, 139296. [CrossRef] [PubMed]

83. Stubenrauch, J.; Ekardt, F. Plastic Pollution in Soils: Governance Approaches to Foster Soil Health and Closed Nutrient Cycles. Environments 2020, 7, 38. [CrossRef]

84. De Souza Machado, A.A.; Lau, C.W.; Till, J.; Kloas, W.; Lehmann, A.; Becker, R.; Rillig, M.C. Impacts of Microplastics on the Soil Biophysical Environment. Environ. Sci. Technol. 2018, 52, 9656-9665. [CrossRef]

85. Rillig, M.C.; Ziersch, L.; Hempel, S. Microplastic transport in soil by earthworms. Sci. Rep. 2017, 7, 1-6. [CrossRef]

86. Li, S.; Wang, P.; Zhang, C.; Zhou, X.; Yin, Z.; Hu, T.; Hu, D.; Liu, C.; Zhu, L. Influence of polystyrene microplastics on the growth, photosynthetic efficiency and aggregation of freshwater microalgae Chlamydomonas reinhardtii. Sci. Total Environ. 2020, 714, 136767. [CrossRef]

87. Canniff, P.M.; Hoang, T.C. Microplastic ingestion by Daphnia magna and its enhancement on algal growth. Sci. Total Environ. 2018, 633, 500-507. [CrossRef] [PubMed]

88. Romera-Castillo, C.; Pinto, M.; Langer, T.M.; Álvarez-Salgado, X.A.; Herndl, G.J. Dissolved organic carbon leaching from plastics stimulates microbial activity in the ocean. Nat. Commun. 2018, 9, 1-7. [CrossRef] [PubMed]

89. Urbanek, A.K.; Rymowicz, W.; Mirończuk, A.M. Degradation of plastics and plastic-degrading bacteria in cold marine habitats. Appl. Microbiol. Biotechnol. 2018, 102, 7669-7678. [CrossRef] [PubMed]

90. Tokiwa, Y.; Calabia, B.P. Review Degradation of microbial polyesters. Biotechnol. Lett. 2004, 26, 1181-1189. [CrossRef] [PubMed]

91. Yu, Y.; Li, H.; Zeng, Y.; Chen, B. Extracellular enzymes of cold-adapted bacteria from Arctic sea ice, Canada Basin. Polar Biol. 2009, 32, 1539-1547. [CrossRef]

92. Sen, S.; Puskas, J.E. Green Polymer Chemistry: Enzyme Catalysis for Polymer Functionalization. Molecules 2015, 20, 9358-9379. [CrossRef] [PubMed]

93. Kobayashi, S.; Makino, A. Enzymatic Polymer Synthesis: An Opportunity for Green Polymer Chemistry. Chem. Rev. 2009, 109, 5288-5353. [CrossRef]

94. Guebitz, G.; Cavaco-Paulo, A. Enzymes go big: Surface hydrolysis and functionalisation of synthetic polymers. Trends Biotechnol. 2008, 26, 32-38. [CrossRef]

95. Biundo, A.; Hromic, A.; Pavkov-Keller, T.; Gruber, K.; Quartinello, F.; Haernvall, K.; Perz, V.; Arrell, M.S.; Zinn, M.; Ribitsch, D.; et al. Characterization of a poly(butylene adipate-co-terephthalate)-hydrolyzing lipase from Pelosinus fermentans. Appl. Microbiol. Biotechnol. 2015, 100, 1753-1764. [CrossRef]

96. Mochizuki, M.; Hirano, M.; Kanmuri, Y.; Kudo, K.; Tokiwa, Y. Hydrolysis of polycaprolactone fibers by lipase: Effects of draw ratio on enzymatic degradation. J. Appl. Polym. Sci. 1995, 55, 289-296. [CrossRef]

97. Tokiwa, Y.; Ando, T.; Suzuki, T.; Takeda, K. Biodegradation of Synthetic Polymers Containing Ester Bonds. ACS Symp. Ser. 1990, 433, 136-148.

98. Amass, W.; Amass, A.; Tighe, B. A review of biodegradable polymers: Uses, current developments in the synthesis and characterization of biodegradable polyesters, blends of biodegradable polymers and recent advances in biodegradation studies. Polym. Int. 1998, 47, 89-144. [CrossRef]

99. Wei, R.; Zimmermann, W. Microbial enzymes for the recycling of recalcitrant petroleum-based plastics: How far are we? Microb. Biotechnol. 2017, 10, 1308-1322. [CrossRef] [PubMed]

100. Biundo, A.; Ribitsch, D.; Guebitz, G.M. Surface engineering of polyester-degrading enzymes to improve efficiency and tune specificity. Appl. Microbiol. Biotechnol. 2018, 102, 3551-3559. [CrossRef] [PubMed]

101. Tournier, V.; Topham, C.M.; Gilles, A.; David, B.; Folgoas, C.; Moya-Leclair, E.; Kamionka, E.; Desrousseaux, M.-L.; Texier, H.; Gavalda, S.; et al. An engineered PET depolymerase to break down and recycle plastic bottles. Nature 2020, 580, 216-219. [CrossRef] [PubMed]

102. Austin, H.P.; Allen, M.D.; Donohoe, B.S.; Rorrer, N.A.; Kearns, F.L.; Silveira, R.L.; Pollard, B.C.; Dominick, G.; Duman, R.; El Omari, K.; et al. Characterization and engineering of a plastic-degrading aromatic polyesterase. Proc. Natl. Acad. Sci. USA 2018, 115, 4350-4357. [CrossRef] [PubMed] 
103. Biundo, A.; Subagia, R.; Maurer, M.; Ribitsch, D.; Syrén, P.-O.; Guebitz, G.M. Switched reaction specificity in polyesterases towards amide bond hydrolysis by enzyme engineering. RSC Adv. 2019, 9, 36217-36226. [CrossRef]

104. Hempel, F.; Lau, J.; Klingl, A.; Maier, U.G. Algae as Protein Factories: Expression of a Human Antibody and the Respective Antigen in the Diatom Phaeodactylum tricornutum. PLoS ONE 2011, 6, e28424. [CrossRef]

Publisher's Note: MDPI stays neutral with regard to jurisdictional claims in published maps and institutional affiliations.

(C) 2020 by the authors. Licensee MDPI, Basel, Switzerland. This article is an open access article distributed under the terms and conditions of the Creative Commons Attribution (CC BY) license (http://creativecommons.org/licenses/by/4.0/). 